\title{
Social Labs: Identifying Latin American Living Labs
}

\section{Sergio Duarte Masi}

Grupo de Investigación en Ciencias de la Información (GICI), Facultad Politécnica, Universidad Nacional de Asunción, San Lorenzo, Paraguay

\section{Email address:}

sedumapy@gmail.com,sduarte@conacyt.gov.py

To cite this article:

Sergio Duarte Masi. Social Labs: Identifying Latin American Living Labs. Humanities and Social Sciences. Vol. 4, No. 3, 2016 , pp. 76-82. doi: 10.11648/j.hss.20160403.12

Received: March 1, 2016; Accepted: May 27, 2016; Published: June 20, 2016

\begin{abstract}
The purpose of this article is to analyze the various areas of intervention of Living Labs in several countries to determine the orientation of their actions. This case study compared the various Living Labs found in Latin America, Europe, Asia and Africa was performed by analysis of secondary information available on the websites of the diverse Living Labs analyzed. It proceeded to concentrate the information found in two tables: one that brings together those dedicated to ICTs and the other focused on social issues and problems, and that is precisely most Latin American, Asians and African Living Labs. This geographical (or geopolitics) differentiation shows how this innovative co-creation methodology has adapted effectively to social realities ruled by inequality, poverty and / or where problems requiring innovative approaches when the search for collective solutions is necessary.
\end{abstract}

Keywords: City Labs, Living Labs, Social Labs, Social Innovation, Co-Creation

\section{Introduction}

The concept of Living Labs was coined by professors William J. Mitchell, Kent Larson and Alex Pentland at the Massachusetts Technology Institute (MIT) during the first decade of the 21 th century. It's a research concept that can be defined as an open innovation ecosystem or environment centered on practices and uses in the field of Information and Communications Technology by the users themselves [1].

One key aspect about Living Labs is the user's vision as an active and competent partner, able to participate positively in the innovation process. The success of the product or service to be developed will depend on the producer-user interaction. It is very important to base this innovation on the needs and wishes of the potential users, keeping in mind that this users "usually represents an heterogeneous group. This implicates the use of creative power by partners/users encouraging their right to influence on this innovations" [2].

The first Living Lab in USA (MIT Living Labs) was created by Mitchell, Larson and Pentland in 2010. In their web site they define:

The convergence of globalization, changing demographics and urbanization is transforming almost every aspect of our lives. We face new choices about where and how we work, live, travel, communicate and maintain health. Ultimately, our societies are being transformed [1].

MIT Living Labs brings together interdisciplinary experts to develop, deploy, and test -in actual living environmentsnew technologies and strategies for design that respond to this changing world. Our work spans in scale from the personal to the urban, and addresses challenges related to health, energy, and creativity.

The MIT scientists considered that Living Labs represents a user-centered research methodology that can be used for testing, design, validation and improvement of multiple and complex solutions involving real life environments. Living $\mathrm{Lab}$ is an "ecosystem where various actors coexists and where an innovation culture is generated, able to secure innovation projects based on co-design and co-creation by all the actors involved". Spanning a particular area of action (a region, a city, a neighborhood, a building), the Living Lab concept implies a whole research and innovation process in which the user is, systematically, a co-creator, a tester and a judge concerning to innovative ideas, scenarios, concepts, applications and technological devices in real life environments. This new way of facing creation and improvement of applied technology in everyday life is based on the communitarian use of goods and services including 
users not just like materials of study but participants in technological development and innovation [3].

\section{Users to Power}

Living Labs did not appear from nothing. They are the result of the deficiency of diverse research methodologies user-centered that previously had tried to integrate user in creation and innovation stages. The collective participation on content generation, for example, has created interesting experiences, just like Wikipedia or Crowdsourcing.

If we consider that $85 \%$ of the problems in new products launched into the market are related to some fail in the design process. The need of rethink the creative processes has become in the recent years indispensable in order to maintain competitiveness. The lack of contemplation of users' real needs and uses when launching new products and services gives as a result that only $18 \%$ of offline innovations launched into the market are successful [4].

The customization of products and services showed up as a new solution to emerging markets. Anyway, "there is a problem of balance between customization and sustainability of the companies, therefore the use of user-driven innovation methodologies can contribute to the solution, through better knowledge and segmentation of the users/consumers' needs and preferences" [5].

There are four types of Living Labs, depending on if they are utilizer-driven, enabler-driven, provider-driven or userdriven. To keep in mind the complexity of the concept of Living Labs will help us, as we'll see later, to decide what is what we want to achieve and, from there, to design strategies of collective innovative creation according to our needs. "The participation in Living Labs can also help companies to create innovations that can have a bigger connection with the user needs and that can also project themselves to the global market in a short period of time" [6].

The Living Labs experiences are not isolated. In fact, a net has been created in Europe involving 129 Living Labs (European Network of Living Labs - EnoLL) in order to coordinate activities and share their results.

\section{An Innovation Network}

A Living Labs network facilitate, first of all, "the extension of the multi-contextuality through wider dimensions, such as regional characteristics, language, cultural particularities and sectorial specifications". The interconnection between diverse Living Labs allows a wider approach and provides an immediate feedback about "the possible acceptance of some products in specific communities in specific regional configurations" [4].

In accordance with ENoLL, a Living Lab is "at the same time a methodology for User-Driven Innovation (UDI) and an organization that, basically, utilize it" [1]. Therefore we can say that the concept of Living Labs refers both to an organization as well as a methodology.

Although Living Labs are recently under study and therefore their nature is still elusive, it's not risky to suppose that they provide four main services, that we took from an article published on Social Science magazine [7]:

- Incubation of ideas and projects;

- Conceptual design of products and services;

- Development of techniques and prototypes; and

- Validation and Improvement.

We can add to these four main activities: Co-creation, and we're talking about the process of co-design that comes from users-producers interaction; Exploration: the instance in which users explore new uses; and Experimentation: that comes on real scenarios, being the moment of final evaluation on the ground by users themselves.

If we follow the trail traced by the authors of the mentioned article we can identify diverse fields of action where Living Labs desenvolve searching for different goals [7], [14]:

- Public Administration: the goal is to generate and maintain an innovative model that increase not just the economic development but also the dialogue between the State and the citizens.

- Universities and content generation centers: such as foundations, institutes and technological transfer platforms, in order to provide knowledge and find at the same time new functions and uses.

- Private Companies: they can use innovation models in order to look for new markets and new business lines.

- Citizens: people in general can take use of innovative development projects in order to achieve personal or professional goals [7].

The authors talk about convergence in adapting this models to the Paraguay's need, taking Living Labs traditional focus on ICT to a social approach.

\section{Social Innovation}

This glide from strictly ICT focus to a social approach has opened a door for Living Labs to implement their innovative methodologies into countries, regions or human groups in urgent needs (access to food, water or health, ecosystems in risk, extreme poverty, etc.). This allows a new dimension (a social dimension) for Living Labs to explore.

"Solutions can not be imposed forcing people to change their behaviour but creating new highly participative systems, fundamental in order to generate behaviour changes. (...) That's how Living Labs are priviledged environments for this kind of approachment, being open ecosystems involving and motivating innovation processes participants, estimulating colaboration between citizens and facilitating and accelerating the creation and sustainability of new markets and business models" [5].

When Living Labs started to focus on identification and solution of social issues in countries, regions and communities of Latin America, Africa and Asia, they managed to include a new and interesting way of humanitarian aid development and assistance in order to achieve social development from an integrator point of view. 
Through this vision, beneficiaries participate actively on the identification of their problems and the search for solutions making easier the implementation of those solutions and the innovative creation of alternative ways to reach their goals.

"In situations with various actors involved, conflicting interests and a wide range of situations, innovation problems can only be properly managed including all those involved in the process through active participation" [5].

Users' participation on products and services' creation, planning, implementation and testing processes is not a new idea. But what actually is new indeed is the application of this participative methodology into what we can call real life, that is to say specific environments where people act and interact, live, work and consume.

"Innovative user is that who conducts the innovation process. He is conscious that he is different from standard users and he can be part of the solution, helping innovation to be sustainable. That is to say that process does not ends with the designed prototype but it starts all over again and innovative user is also committed with the final product's implementation and creation. One more step to innovation models evolution" [3].

Anyway, one aspect that must be taken into account is privacy and ethics regarding interaction between private sector and individuals' uses and practices. "As people become a source of ideas and innovation, it should be an adequate remuneration and an incentive system in order to secure a retribution to all those involved" [8].

As well as a Living Labs network can "increase opportunities of integrating social innovations with technological innovation in a larger scale that contributes to social and economic dynamism" in Europe [3]. It's very interesting for us to ask about the opportunities that could be generated from an hypothetical Latin American Living Labs network, keeping in mind the success reached by the European experience in such a few years.

Living Labs are "taking researchers out of the labs to contexts where real life can stimulate them to innovation". This situation has facilitated both citizens as companies to participate actively in the management of the research development, the design and the production of goods and services in a more collaborative way. "Final users are estimulated to cooperate in a closer way with researchers, developers and designers to test ideas and prototypes. Working as public-private societies, especially at regional and local levels Living Labs present several advantages over closed labs: they stimulate new ideas, provide specific research challenges and allow a constant results evaluation" [9].

Let's take another example that although it happens in Europe it's a good example of the potential that presents Living Labs methodologies in order to approach social problems. We're talking about Portugal, one of the less developed countries of the continent where recent global crisis "increase the need of taking advantage of the larger amount of resources available to create solutions, involving diverse types of knowledge, resources, participation methods and collaboration. Only making the most of the society's potential energy sustainable and long-term success is possible" [5].

The materialization of the Living Lab concept in Portugal, as an innovative initiatives provider environment, had to do with the "integration and coordination of a set of complementary knowledge and competences holding agents: universities, companies, governmental entities and venture capitals". We can add to this set of agents as a fundamental piece the citizen, in its different aspects as user, active or passive participant, consumer and client [5].

So the 14 Living Labs that exist nowadays in Portugal are on their way to a larger integration of its innovation processes as a strategy to adapt to the conflictive and always changing $21^{\text {st }}$ century, where new readings and new approach on social issues are imperative.

But Portugal is not the only country that take Living Labs methodologies to face the challenges of nowadays innovation processes. Many Latin American, African and Asian countries have started to create their own Living Labs experiences in recent years. As we can see in this paper's Appendix, there are many experiences developed in diverse countries such as Brazil, Colombia, Guatemala or Uganda.

\section{Living Labs in Latin America}

So, although Living Labs exists all along Latin America, there's still a long way to go. "Although isolated initiatives concerned about social issues are promoted and funded, these experiences are not incorporated to Latin American official science and technology's agenda. And, at least in Argentina, there's no evidence so far that shows that this experiences has any influence on the official innovation system" [10].

Collective innovation - where problems are more urgent requires the elaboration of new approaches appealing to creativity of the most participants that can be found.

"A solid knowledge base reflects in a society's economic life, estimulating the change and social and economical sustainable development. No society can prosper without some kind of link between innovation sources and knowledge production" [5].

It turns out that most of these social linked experiences take place in Latin American, Asian and African countries, where inequality is larger and problems are bigger. So collective innovation is welcomed in these countries because it could implicate a big step forward to the improvement of life conditions of millions; contributing to the construction of more open societies and estimulating participative processes in politics, economy, health and all the aspects concerning social welfare.

As we have seen through the experience shared by Gumbo et al, the success, for example, achieved by South Africa's rural communities after implementing collective and participative innovation processes shows how Living Labs are tools and methodologies that can actually improve the conditions of living of an entire community. "Underdevelopment and poverty are the key challenges to our modern world that have drawn the attention of NGOs, 
civil society, governments and international companies. Several commitments including UN Millennium Development Goals and World Summit of Information Society have expressed the global interest to the solution of this problems" [11].

Social and economical development in countries as South Africa can benefit directly from a larger civic integration and better participative methods. "Living Labs methodology has eased responsible research with its emphasis on community commitment. Interaction between community, industry and government has provided an unique opportunity for researchers to assume practical researches that can have a positive impact on rural South Africa".

\section{Innovation at South}

A recent study published by Dos Santos Nogueira, Schiavo and Vera shows how "civic labs bring new and untold methodologies tending to promote social and technological innovation contributing therefore to reduce inequality and social asymmetries of different kinds. In Latin America some experience have been identificated that can be considered as civic labs because of the open innovation methodologies they use but not all of them have their origins on technological innovation initiatives. There are also cases that emerged from social innovation proposals" [10].

In Argentina we can quote as an example the Centro Tecnológico Comunitario (CTC) experience from Nono, state of Córdoba, orientated to technological innovation, and GIROS, a communitarian social innovation initiative developed in Rosario, state of Santa Fe.

Inside Argentina's territory these experiences "were promoted through public politics at different levels tending to digital culture divulgation" and also "we can appreciate that these set of identified experiences are dedicated to cultural digital divulgation by offering technological training" [10].

In Brazil, the South American giant, Living Labs started in 2009 and by 2012 there were 12 Brazilian groups integrated to ENoLL. The factors that motivated the accession of Brazilian Living Labs to that European network has to do with the possibility of access to international knowledge and resources.

Most of Brazilian Living Labs are dedicated to social innovation and not to commercial innovation. Anyway, if we talk about specific results, there is some kind of balance between technological and social innovation. Just like Magdala Pinto and Pedruzzi Fonseca says: "one of the main challenges is the lack of specific resources for this kind of initiative and the isolation regarding other Living Labs. (...)
That's way the necessity of identify these initiatives and spread Living Labs concept and methodology is very important in order to improve this experiences inside the country and overcome their challenges" [12].

The potential of these user-driven design and innovation participative approaches has already been studied, as we saw before, mainly in Europe and USA but we realize that academic papers regarding its development in Latin America are still few.

We agree with Dell'Era and Landoni when they say that "more analysis are needed in order to have a better understanding about Living Labs functioning, more effective management models and which organizations could benefit from this methodologies" [12].

\section{Conclusion}

Living Labs and similar spaces concerned about social issues and problems have rich fields to develop and grow in Latin America, Africa and Asia. In Europe and USA, on the other hand, we see Living Labs more concerned about ICTs.

This geographic (or geopolitical) difference shows how this innovative co-creation methodology has effectively adapted to social realities where inequality rules, poverty are installed and where innovative approaches are needed in order to build collective solutions.

We also notice the co-existence between these two approaches and the existence of a mix point of view. Anyway, these hybrid experiences are easier to find on Living Labs and similar spaces related to ICTs.

As we just wrote a few lines before, one key aspect to keep in mind is the need of think on privacy in a system that puts people/users at the center of the whole creative process where private-public borders are easily blurred.

Let's take Amaral de Brito and De Oliveira conclusions: "perhaps more than ever now is the time for a reflection (...) that can lead us to new social and economic models in order to guarantee a better sustainability and a wider welfare for all citizens, demands that we have to face now" [5].

Maybe it's time to start to differentiate those Living Labs dedicated to ICTs from those focused on social problems. We consider relevant to suggest the words Social Labs to refer to the second group.

This way, we suppose, we'll be able to identify and advance in our understanding of collective and innovative solutions to social problems where people involved can participate on creation processes and improve the tools and methods in order to build a better life for all.

\section{Appendix I}

Table A1. Some examples of Living Labs concerned about Social Issues.

\begin{tabular}{llll}
\hline Name & Country & Intervention areas & Web site \\
\hline Habitat LL & Brazil & $\begin{array}{l}\text { Technology, environment, improvement of low-income } \\
\text { communities housing conditions. }\end{array}$ & http://web3.ufes.br/habitat/organizacao_en.html \\
Amazonas LL & Brazil & Aging and longevity research & $\begin{array}{l}\text { http://www.zorgproeftuinen.be/nl/nl/platforms/ai } \\
\text { pa-ageing-place-aalst }\end{array}$ \\
\hline
\end{tabular}




\begin{tabular}{|c|c|c|c|}
\hline Name & Country & Intervention areas & Web site \\
\hline Habitat LL & Brazil & Sustainable technology research for vulnerable communities & http://www.labtar.net.br/site/habitat/ \\
\hline $\begin{array}{l}\text { Brazilian Biotech } \\
\text { Innovation LL }\end{array}$ & Brazil & Biotechnology research, innovation and development. & $\begin{array}{l}\text { http://www.openlivinglabs.eu/livinglab/brazilian- } \\
\text { biotech-innovation-living-lab }\end{array}$ \\
\hline $\begin{array}{l}\text { The Rehabilitation } \\
\text { Living Lab in the mall }\end{array}$ & Canada & $\begin{array}{l}\text { Research and development of strategies for social inclusion } \\
\text { of people with disabilities. }\end{array}$ & http://www.crir-livinglabvivant.com/ \\
\hline Le Mandalab & Canada & Social work on vulnerable communities. & http://www.communautique.qc.ca/ \\
\hline Green China Lab & China & Sustainable technology innovation. & http://www.greenchinalab.org/ \\
\hline Guacarí LL & Colombia & $\begin{array}{l}\text { Health, Education, Tourism, Government and Economic } \\
\text { Development. }\end{array}$ & http://www.guacaridigital.gov.co/ \\
\hline CINTEL & Colombia & ICT aid to vulnerable communities. & http://www.cintel.org.co/ \\
\hline ExPin LL & Colombia & Bridging the digital divide & $\begin{array}{l}\text { http://www.openlivinglabs.eu/livinglab/expin- } \\
\text { living-lab }\end{array}$ \\
\hline Hygée Lab & France & Faight against cancer & $\begin{array}{l}\text { http://openlivinglabs.eu/livinglab/hyge } \% C C \% 81 \\
\text { e-lab }\end{array}$ \\
\hline eCare Lab & France & Technological innovation in Heatlh & http://www.medicalps.eu/ \\
\hline AutonomLab & France & ICT innovation for Health social inclusion. & http://www.autonom-lab.com/ \\
\hline $\begin{array}{l}\text { Issy-les-Moulineaux } \\
\text { Medialand }\end{array}$ & France & Civic transparency and co-participation through ICT & $\begin{array}{l}\text { http://issy.com/index.php/fr/english/economy/we } \\
\text { lcome_to_medialand }\end{array}$ \\
\hline HumanTech LL & Finland & Smart and sustainable urbanism. & http://www.jamk.fi/en/Home/ \\
\hline ERILiving Lab & Guatemala & $\begin{array}{l}\text { Sustainable industries development in vulnerable } \\
\text { communities. }\end{array}$ & http://www.erilivinglab.com/home.html \\
\hline CASALA LL & Ireland & ICT innovation for elderly inclusion. & http://www.casala.ie/ \\
\hline Green Schools & Italy & Sustainable schools construction. & http://www.100scuole.it/ \\
\hline $\begin{array}{l}\text { Lecco Innovation } \\
\text { Living Lab }\end{array}$ & Italy & Health and rehabilitation. & http://www.leccolivinglab.com/ \\
\hline Smart Village LL & India & Education, energy and sustainable life. & $\begin{array}{l}\text { https://in.linkedin.com/pub/svll- } \\
\text { india/103/853/235 }\end{array}$ \\
\hline Berytech LL & Lebanon & $\begin{array}{l}\text { Technological innovation for social inclusion and regional } \\
\text { development. }\end{array}$ & http://www.berytech.org/ \\
\hline $\begin{array}{l}\text { Innovative Learning \& } \\
\text { Teacher Education LL }\end{array}$ & Mauritius & $\begin{array}{l}\text { Technological innovation for holistic and sustainable } \\
\text { education. }\end{array}$ & $\begin{array}{l}\text { http://openlivinglabs.eu/livinglab/innovative- } \\
\text { learning-teacher-education-living-lab-iltell }\end{array}$ \\
\hline Kathmandu LL & Nepal & $\begin{array}{l}\text { Technological solutions for everydays problems (water, } \\
\text { food, health, transport, etc.) }\end{array}$ & http://kathmandulivinglabs.org/ \\
\hline Cedic LL & Paraguay & $\begin{array}{l}\text { Health, Education, Environment and Sustainable } \\
\text { development. }\end{array}$ & www.cedicpy.com \\
\hline $\begin{array}{l}\text { African Living Lab } \\
\text { ISEG/UDINAF }\end{array}$ & Senegal & $\begin{array}{l}\text { Integration and sustainable development and reduction of } \\
\text { the digital divide in Africa. }\end{array}$ & http://www.isegcesmi.com.20/ \\
\hline Energy Living Lab & Switzerland & Innovation in renewable energy. & $\begin{array}{l}\text { https://energylivinglab.atizo.com/platform/organi } \\
\text { sation/ }\end{array}$ \\
\hline $\begin{array}{l}\text { DigiArt Living Lab } \\
\text { Tunis - Nabeul }\end{array}$ & Tunisia & Innovative support to young professionals. & http://www.3dnetinfo.com/ \\
\hline User Experience LL & $\begin{array}{l}\text { Trinidad } \\
\text { and Tobago }\end{array}$ & Work spaces development on sustainable habitats. & http://www.sta.uwi.edu/ \\
\hline Living goods LL & Uganda & Innovation on health, attention and prevension. & http://livinggoods.org \\
\hline
\end{tabular}

\section{Appendix II}

Table A2. Some examples of Living Labs focused on ICT.

\begin{tabular}{|c|c|c|c|}
\hline Name & Country & Intervention areas & Web site \\
\hline Experimental Factory Magdeburg & Germany & Industrial production innovation. & $\begin{array}{l}\text { http://www.mimoa.eu/projects/Germany/Magdeburg/Expe } \\
\text { rimental\%20Factory/ }\end{array}$ \\
\hline Virtual Dimension Center & Germany & $\begin{array}{l}\text { Industrial technology research, } \\
\text { experimentation and innovation. }\end{array}$ & $\begin{array}{l}\text { http://www.germaninnovation.org/research-and- } \\
\text { innovation/centers-of-innovation/center-of- } \\
\text { innovation?id=93651a6b-0d93-e211-8298-000c29e5517f }\end{array}$ \\
\hline Mobile City Bremen & Germany & ICT innovation and research & $\begin{array}{l}\text { http://www.uni-bremen.de/a-bis- } \\
\text { z/institutionen/xml/Connector/show/806 }\end{array}$ \\
\hline Adelaide Living Laboratories & Australia & $\begin{array}{l}\text { Research and scientific intervention in } \\
\text { communities. }\end{array}$ & $\begin{array}{l}\text { http://www.unisa.edu.au/Research/zerowastecentre/Our- } \\
\text { research/ }\end{array}$ \\
\hline $\begin{array}{l}\text { Transports and Logistics Living } \\
\text { Labs }\end{array}$ & Australia & $\begin{array}{l}\text { Encounter space between the State, } \\
\text { the companies and users for to } \\
\text { improve transport services. }\end{array}$ & http://www.futurelogisticslivinglab.com.au/ \\
\hline CityLab Graz & Austria & $\begin{array}{l}\text { Urbann environment research and } \\
\text { technological development. }\end{array}$ & http://www.stadtlaborgraz.at/index.php/en/thecitylabis \\
\hline Mobile City Bregenz & Austria & $\begin{array}{l}\text { Innovation and research on mobile } \\
\text { and Internet technology: uses and }\end{array}$ & $\begin{array}{l}\text { https://www.bregenz.gv.at/buergerservice- } \\
\text { verwaltung/dienstleistung/mobile-city-bregenz.html }\end{array}$ \\
\hline
\end{tabular}




\begin{tabular}{|c|c|c|c|}
\hline Name & Country & Intervention areas & Web site \\
\hline & & creativity. & \\
\hline ONLINE Communities & Belgium & Public-Private relationship. & http://www.zorgproeftuinen.be/en \\
\hline iMinds iLabs.o & Belgium & $\begin{array}{l}\text { Collective innovation on commercial } \\
\text { politics and strategies. }\end{array}$ & http://www.iminds.be/ \\
\hline LeYLab & Belgium & $\begin{array}{l}\text { Urban environments digital } \\
\text { innovation. }\end{array}$ & http://www.alcatel-lucent.com/ \\
\hline JF Ocean & Belgium & $\begin{array}{l}\text { Interdisciplinary commercial co- } \\
\text { innovation. }\end{array}$ & http://www.jfocean.com \\
\hline Llio & Canada & $\begin{array}{l}\text { Regional touristic and rural } \\
\text { development. }\end{array}$ & http://www.llio.quebec \\
\hline Living Lab Shanghai & China & Knowledge social building. & http://sfc.tongji.edu.cn \\
\hline Living Lab Antioquia & Colombia & Knowledge collective building. & http://www.paisdelconocimiento.org/antioquiall \\
\hline Rijeka iLiving Lab & Croatia & $\begin{array}{l}\text { Technological innovation on shipping } \\
\text { trade and navigation. }\end{array}$ & http://www.pfri.eu/ \\
\hline DOLL & Denmark & Urban ecological transformation. & http://www.lightinglab.dk/UK/ \\
\hline Digital Urban Living Labs & Denmark & Living Labs network & http://www.regionmidtjylland.dk/ \\
\hline Copenhagen Living Lab & Denmark & Commercial innovation & http://copenhagenlivinglab.com/ \\
\hline $\begin{array}{l}\text { Helsinki Living Labs (Forum } \\
\text { Virium) }\end{array}$ & Finland & Products and services development & http://www.helsinkilivinglab.fi/ \\
\hline Smart City Lab & Estonia & Integrated digital city innovation & http://smartcitylab.eu/cluster/ \\
\hline Roswell Voices LL & USA & Rebuilding of collective identity. & http://www.uga.edu/ \\
\hline MIT Living Labs & USA & Innovative technological strategies. & http://livinglabs.mit.edu/ \\
\hline Library Living Lab Barcelona & Spain & $\begin{array}{l}\text { Collective knowledge and content } \\
\text { generation. }\end{array}$ & http://13.cvc.uab.es/ \\
\hline Streetlab & France & $\begin{array}{l}\text { Urban technological innovation for } \\
\text { blind people }\end{array}$ & http://www.streetlab-vision.com/ \\
\hline Images \& Réseaux-ImaginLab & France & Mobile innovation & http://imaginlab.fr/blog-en/ \\
\hline LL ICT Usage Lab & France & Services and products innovation. & http://openlivinglabs.eu/livinglab/ll-ict-usage-lab \\
\hline Normandy Living Lab & France & Regional ICT innovation. & http://www.pole-tes.com/normandy-living-lab/ \\
\hline Digital Home Living Lab (DHLL) & France & ICT experimental house. & $\begin{array}{l}\text { http://www.openlivinglabs.eu/livinglab/digital-home- } \\
\text { living-lab }\end{array}$ \\
\hline Laurea LL Network & Finland & Urban services applied sciences. & http://www.laurea.fi/ \\
\hline Formedil Lab & Italia & $\begin{array}{l}\text { Building industry innovative } \\
\text { education. }\end{array}$ & http://formedillab.it \\
\hline Krakow Living Lab & Poland & Regional digital innovation. & http://www.kpt.krakow.pl/ \\
\hline $\begin{array}{l}\text { Birmingham Communities Building } \\
\text { Capacity }\end{array}$ & UK & ICT comunitary training. & http://www.digitalbirmingham.co.uk/cbc \\
\hline THINKlab & UK & Trades and products development. & http://thinklab.co.uk/ \\
\hline Manchester Digital Innovation LL & UK & Digital innovation. & http://www.mmu.ac.uk/ \\
\hline SILab & UK & Knowledge collective development. & http://www.ncl.ac.uk/kite/ \\
\hline Lab4Living & UK & Health research and innovation. & http://www.lab4living.org.uk/ \\
\hline iHomeLab & Switzerland & Smart Building innovation. & http://www.ihomelab.ch/ \\
\hline $\begin{array}{l}\text { Mobile Comunications and } \\
\text { Computing for Quality of Life }\end{array}$ & Switzerland & Mobile innovation. & http://www.qol.unige.ch/mQoL.html \\
\hline Living Labs Taiwan & Taiwan & Technological innovation & http://www.iii.org.tw/ \\
\hline $\begin{array}{l}\text { Smart City Istanbul Living Lab } \\
\text { (SCILL) }\end{array}$ & Turkey & Smart cities ICT application. & $\begin{array}{l}\text { http://openlivinglabs.eu/livinglab/smart-city-istanbul- } \\
\text { living-lab-scill }\end{array}$ \\
\hline
\end{tabular}

\section{References}

[1] Mit (2010): Our Mission [online]. Living Labs, Massachusetts Institute of Technology. Available in: http://livinglabs.mit.edu [Consulted in March 2016].

[2] Bergvall-Kareborn, B; Ihlström Eriksson, C; Lund, J. and
Strahbröst, A. (2009): A Milieu for Innovation - Defining Living Labs [online]. Lulea University of Technology Halmstad University. Available in: http://www.researchgate.net/publication/228676111 [Consulted in March 2016].

[3] Galaso, J. A. (2013): Metodología de innovación con ciudadanos por el CitiLab de Cornellà. CTS Magazine \#23, vol. 8, May: 249-258. 
[4] Feurstein, K; Hesmer, A; Hribernik, K. A; Schumacher, J. and Thoben, K. D. (2008): Living Labs: a new development strategy [online]. European Living Labs - A New Approach for Human Centric Regional Innovation. Universität Bremen. Berlin. Available in: http://www.researchgate.net/p[Consulted in March [2016] ublication / 270821724 European Living Labs A New Approach for Human Centric Regional Innovation [Consulted in March 2016]

[5] Amaral De Brito, D. and De Oliveira, A. (2013): Living Labs: A experiência Portuguesa. CTS Magazine \#23, vol. 8, May: 201-229.

[6] Leminen, S; Nyström, A. and Westerlund, M. (2012): Living Labs as Open-Innovation Networks. Technology Innovation Management Review. September 2012: 6-11.

[7] Arias Rojas, F; Duarte Masi, S; Dorigo, D; Rojas De Arias, A. and Rolon, M. (2014): Living Labs, Spaces for Open Innovation and Technology Transfer. An Alternative to the Solution of Social Problems in Paraguay [online]. Social Sciences \# 3 Vol. 3. Available in: http:www.sciencepublishinggroup.com/j/ss [Consulted in March 2016].

[8] Niitamo, V. P; Kulkki, S; Eriksson, M. and Hribernik, K. A. (2008): State-of-the-Art and Good Practice in the Field of Living Labs [online]. IST Project CoreLabs - Co-creative. European Commission. No. IST-FP6-035065. Available in: http://www.researchgate.net/publication/228367848_State-ofthe-art_and_good_practice_in_the_field_of_living_labs [Consulted in March 2016] Almirall, E; Lee, M. and Wareham, J. (2012): Mapping Living Labs in the Landscape of Innovation Methodologies. Technology Innovation Management Review. September 2012: 12-18.
[9] Conte, R. and Santoro, R. (2009): Living Labs in Open Innovation. Functional Regions. 15th International Conference on Concurrent Engineering (ICE 2009). Leiden: 22-24.

[10] Dos Santos Nogueira, C; Schiavo, E. and Vera, P. (2013): Entre la divulgación de la cultura digital y el surgimiento de los laboratorios ciudadanos. El caso argentino en el contexto latinoamericano. CTS Magazine \#23, vol. 8, May: 179-199.

[11] Gumbo, S; Hansen S; Terzoli, A; Thinyane, H. and Thinyane, M. (2012): Living Lab Methodology as an Approach to Innovation in ICT4D: The Siyakhula Living Lab Experience [online]. IST-Africa 2012 Conference Proceedings (Eds). IIMC. Available in: www.IST-Africa.org/Conference2012 [Consulted in March 2016] Bauer, R. (2004): No need for plastic wheels [online]. In: Freitag, Issue 43. Frankfurt. Quoted in: http://www.bik.unibremen.de/BIK_Daten/pdf_daten/3_2008_Feu_342.pdf [Consulted in March 2016]

[12] De Magdala Pinto, M. and Pedruzzi Fonseca, L. (2013): Profundizando la comprensión de los Living Labs de Brasil. CTS \#23, vol.8, May: 231-247.

[13] Dell'era, C. and Landoni, P. (2014): Living Lab: A Methodology between User-Centred Design and Participatory Design. Creativity and Innovation Management \#2, Vol. 23: 137-155.

[14] García Guzmán, J; Merz, C. and Schaffers, H. (2009): Living Labs for Enchancing Innovation and Rural Development. Methodology and Implementation. eJOV Executive - The Electronic Journal for Virtual Organizations and Networks. Volume 11. 